\title{
Device for quantitative collection of chicken excrements in balance studies*
}

\author{
L. Grešáková ${ }^{1}$, K. Boldižárová ${ }^{1}$, S. Kuricová ${ }^{1}$, M. Levkut ${ }^{2}$ \\ and L. Leng ${ }^{1,3}$
}

\author{
${ }^{1}$ Institute of Animal Physiology, Slovak Academy of Sciences \\ Šltésovej 4, 04001 Košice, Slovak Republic \\ ${ }^{2}$ Institute of Pathological Anatomy, University of Veterinary Medicine \\ Komenského 73, 04181 Košice, Slovak Republic
}

(Received 18 July 2002 ; revised version 24 January 2003; accepted 4 April 2003)

\begin{abstract}
A simple method for quantitative collection of chicken excreta directly into plastic bags is described. The feathers neighbouring the cloaca are cut off and a polyethylene PE bag is sealed firmly to the body just around the cloaca using double-sided adhesive tape. Birds fitted with PE bags for a balance experiment were housed individually in plastic boxes for the next 6 days. The collection bags placed around the cloaca were changed each day during the balance measurement period. The described method proved to be an effective and inexpensive tool for the quantitative collection of excrement in chickens. The advantage of this approach is direct collection of samples into PE bags, which prevents their loss and contamination with feed during balance measurements of nutrients.
\end{abstract}

KEY WORDS: chicken, excrement collection, balance measurements

\section{INTRODUCTION}

Balance measurements of nutrients in animals require precise, long-term quantitative collection of excrements. Methods of excrement collection in poultry have been described in many papers (Gažo et al., 1959; Blakely, 1963; Almeida and Baptista, 1984; Sibbald and Wolynetz, 1986, 1987). Most frequently, approaches with birds housed in wire-floored cages were exploited. Collection trays made of plastic

\footnotetext{
* Supported by the Grant Agency for Science, VEGA of Slovak Republic, Grant No 2/3066/23

3 Corresponding author: lleng@saske.sk
} 
or other suitable material as a device for retaining excrements are placed below the wire-netting floors to retain excrement (Antalíková et al., 2001).

The development of alternative methods of the excrement collection in poultry has been the subject of investigation. Blakely (1963) described a technique based on the suturing of a collecting device to the skin around the turkey cloaca. Another approach was attaching self-adhesive human colostomy bags to the skin and feathers around the cloaca with an adhesive (Sibbald, 1983). A harness for holding plastic collection bags was developed by Almeida and Baptista (1984). Its modified version was used in the estimation of energy and nitrogen excretion in cockerels (Sibbald, 1986; Sibbald and Wolynetz, 1986).

This paper describes our method of direct quantitative collection of chicken excrements into inexpensive plastic polyethylene (PE) bags. It eliminates any contamination of the excrement samples. The technique is simple and can be applied in various experimental protocols dealing with nutrition and/or metabolic studies in chickens.

\section{MATERIAL AND METHODS}

The experiments were carried out on 28 four-week-old and 24-eight-week-old female chickens of the laying strain Isa Brown. During the procedure of excreta collection into the bags the birds were housed individually in plastic boxes $(60 \mathrm{x}$ $40 \times 35 \mathrm{~cm}$ ) covered with a wire net. A $10 \times 10$ window was made in the wire net covering. Chickens were reared with a lighting regimen of 15L:9D and temperature of $23^{\circ} \mathrm{C}$. All animals had free access to water and feed. Each box was furnished with one vessel for tap water and with another one for a precisely preweighed amount of feed. The vessels were placed in the opposite corners of boxes to prevent mutual contamination. The birds were allowed to adapt to individual housing in the boxes and also to the plastic bags placed around the cloaca for at least 3 days. The bags with samples of excrements for experimental analysis were collected for the following 6 days.

\section{The technique of attachment of PE-bags to the chicken's body}

The chickens were immobilized by holding their legs and wings. A few feathers growing near the cloaca were gently cut off. Double-sided Universal adhesive tape (TESA) about 25 to $28 \mathrm{~cm}$ in length and $2.5 \mathrm{~cm}$ wide was prepared in advance for a four-week-old bird. Obviously, the length of the tape should be adjusted to the size of the animal. Then we attached the tape by its uncovered (adhesive) side around the caudal part of the body under the cloaca. Sealing the tape to the body started from its upper part (regio synsacralis) and continued around the 
body to the starting point. The tape can also be attached to the midpoint of the abdominal part of the body just behind the caudal tip of the chest bone (regio sternalis) and both ends of the tape are joined at regio synsacralis. For proper positioning, the total length of sealing tape should be about $2 \mathrm{~cm}$ longer than the circumference of the chicken body. Winding the tape in this way firmly connects it to the bird's body (Figure 1).

We continue by stripping the protective covering (see arrow on Figure 2) from the outer side of the double-sided tape. This step should be done carefully to prevent sticking of adjacent feathers or wings to the tape. Finally, both ends of the tape are joined by mutual overlapping over a length of approximately $2 \mathrm{~cm}$ (Figure 2).

Bags $24 \mathrm{~cm}$ in length and $16 \mathrm{~cm}$ wide from recyclable polyethylene (microten PE-HD 02) were marked by a waterproof pen and used for 4-week-old-chickens. Bags measuring $30 \mathrm{~cm}$ in length and $20 \mathrm{~cm}$ in width were applied to 8 -week-old birds. To adjust the position of the bag on the chicken's body, the edges of its opening were folded once or twice. The bag was carefully drawn onto the chicken's body from the bottom of the caudal site and its edges carefully attached to the adhesive side of the tape along the entire circumference. The remaining parts of the edges unattached to the tape due to the a larger size of the bag opening than the circumference of the chicken body were simply stuck to the underlying PE-foil by another piece of tape. This connection of the remaining bag edges must be placed on the dorsal part of chicken body (Figure 3).

The lowest corner of the fixed bag should be some $3-4 \mathrm{~cm}$ above the ground level so as not to restraining the bird's movements. The firmness of the attachment of bag to the chicken body was checked once more and finally the chickens were placed individually into clean plastic boxes (Figure 4).

The collection bags were removed from chickens once daily simply by cutting them with scissors. New, clean bags were applied immediately. The tape holding the bag can be removed too, but in such a case it must be substituted with a new one. Most often the original tape remained on the chicken's body and a new tape was stuck on it. The first possibility was preferred only in cases if a large numbers of feathers was stuck to the original holding tape.

\section{Balance measurements and sample handling}

Each bird was weighed daily after the removal of collection bag with excrements. The spilled feed on the floor of boxes was separated from feathers, fluff and scale by gentle blowing and collected with the help of a brush. In the balance experiment, collected feed was weighed together with the remaining feed from the relevant vessel. The vessels in clean boxes were refilled with tap water and pre-weighed amounts of food for the next day of excrement collection. The daily collected amounts of the excrements were weighed, dried in an oven at $55^{\circ} \mathrm{C}$ 


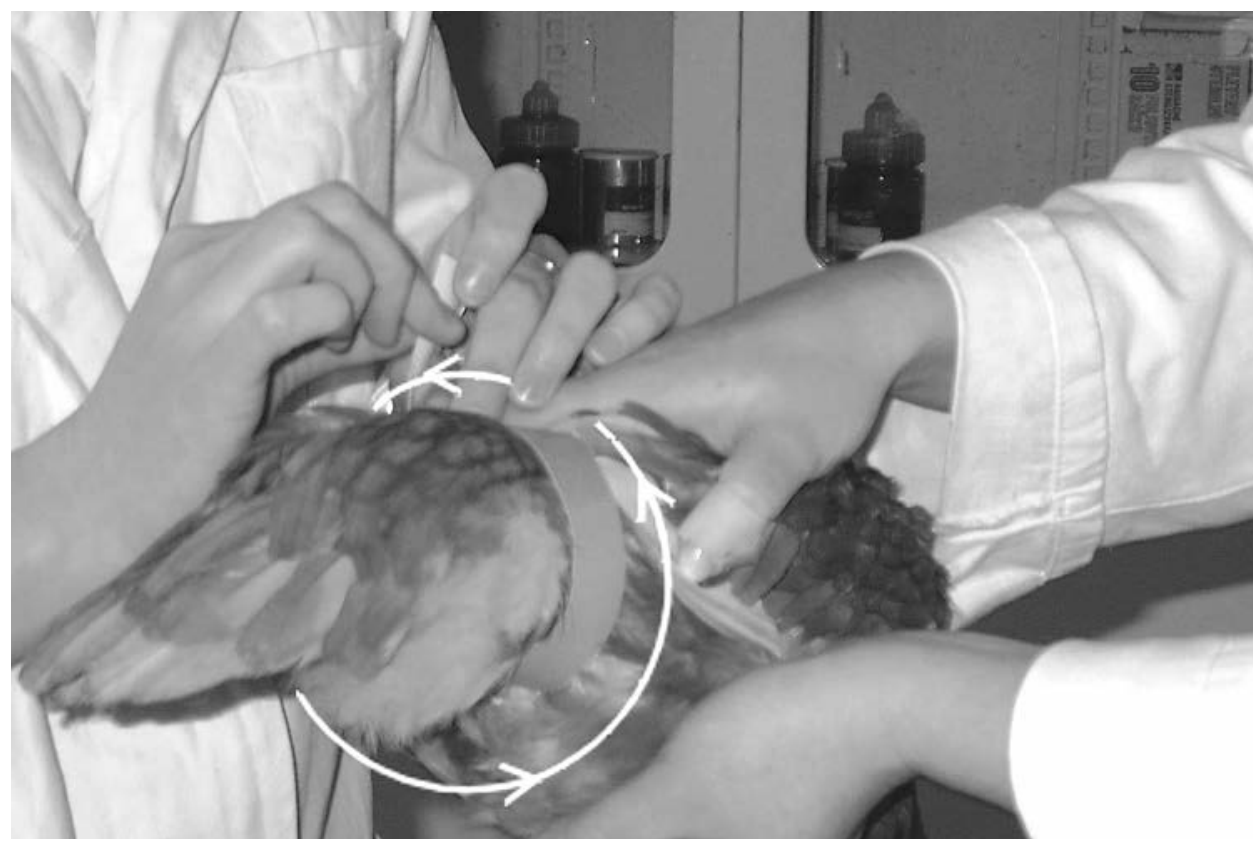

Figure 1. The attachment of the double-side adhesive tape to the caudal part of chicken body around the cloaca

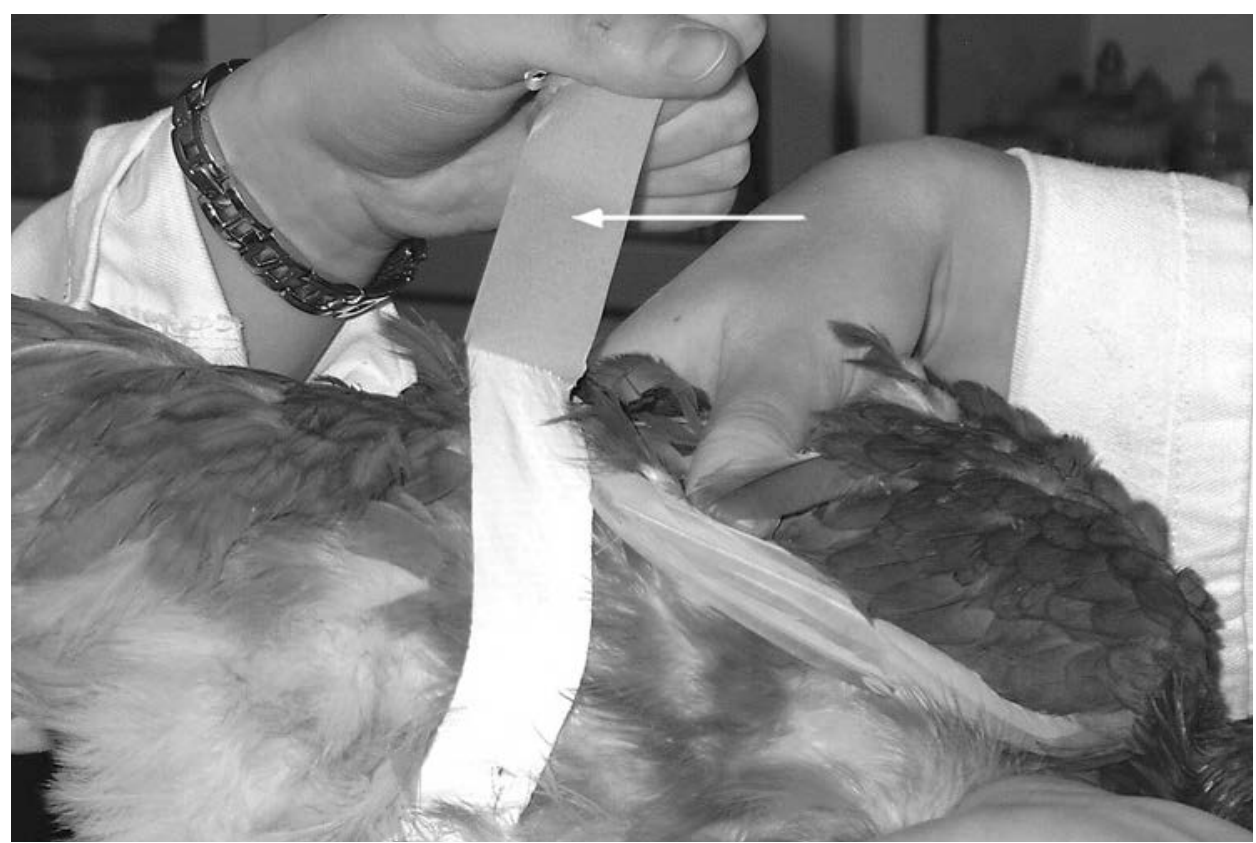

Figure 2. The stripping of protective foil from a covered side of body sealed double-side tape 


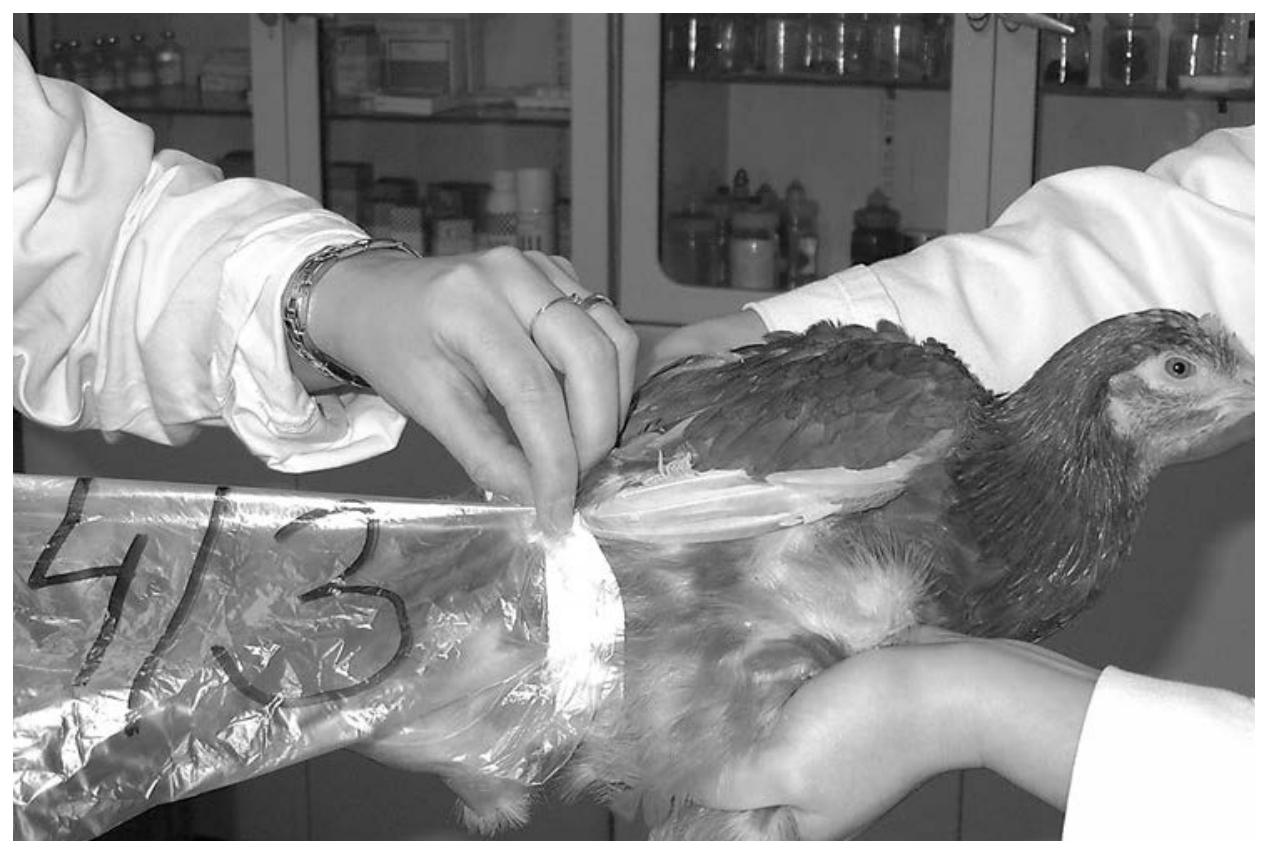

Figure 3. The placing of the collection bag on the adhesive side of tape sealed along the whole perimeter of caudal part of chicken body

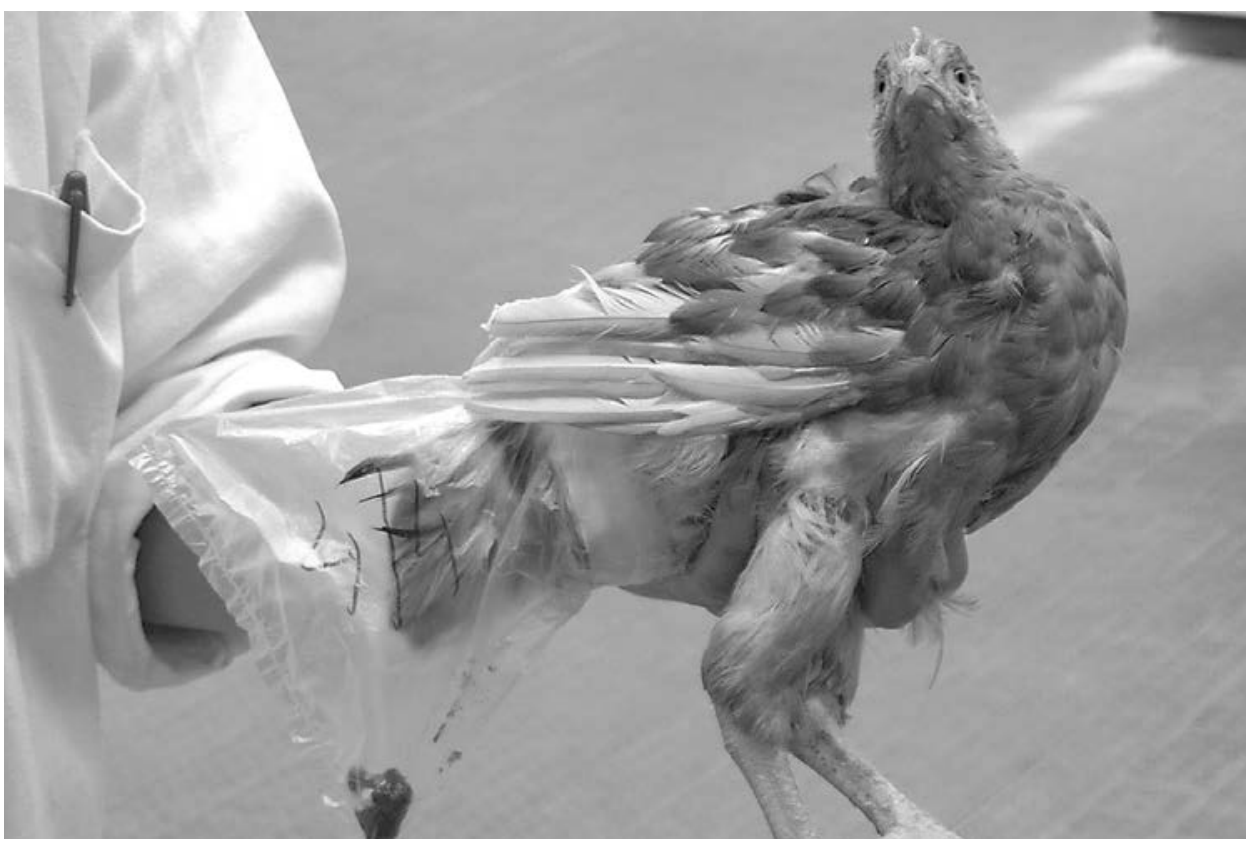

Figure 4. The final look at chicken fitted with a bag for the collection of excrements 
to a constant dryness for $48 \mathrm{~h}$ and were ground in a mortar before analysis. A standard procedure of excrement drying in an oven at $105^{\circ} \mathrm{C}$ was used to determine the dry matter contents.

\section{RESULTS AND DISCUSSION}

We found only eleven leaking collection bags during a 6-day long balance experiment on 52 birds. Such damaged samples could not be included in the balance estimation. This meant $3.53 \%$ of a total of 312 collected samples only. The common reason for these failures was a hole developing in the bag or tearing due to excessive length. Chickens tore bags that were too long with their feet. Pecking at too long bags contributed to their damage and subsequent loss of excrement. On the other hand, bags that are either too small or too short are also not useful. Too short bags usually cause adherence of collected excrements to the cloaca and to the feathers around it, also resulting also in a significant losses of sample. In other words, any underestimation of the proper bag size can result in failure of quantitative collection of excreta in chickens.

The average values of feed intake, excreta collected and body weights in chickens during a 6-day-procedure of excreta collection are summarized in Table 1. Chickens had free access to feed in our experiments. Comparing to reference values 27.9 and $47.9 \mathrm{~g} /$ day (Jordan and Pattison, 1996), the intake of feed was reduced in both 4- and 8-week-old birds by 23.3 and $10.5 \%$, respectively. It seems that this phenomenon was also caused by some stress due to individual housing of birds because they naturally live in flocks. An interesting finding was that feed intake reached almost the reference value in 8-week-old chickens. One can only speculate that larger birds were less stressed by individual housing because they reached the net window and could see the other birds in neighbouring cages. To overcome the problems with the amount of feed intake, the birds in balance studies are usually force-fed by intubation of the oesophagus (Sibbald and Wolynetz, 1987, 1989; King et al., 1997).

TABLE 1

Daily intake of feed, dry matter excreted and body weight of 4 and 8 weeks old chickens of laying strain Isa Brown during excreta collection into bags. Values are means \pm SEM of six days lasting measurements

\begin{tabular}{lccc}
\hline Chickens & $\begin{array}{c}\text { Intake of feed } \\
\text { g/day }\end{array}$ & $\begin{array}{c}\text { Dry matter excreted } \\
\text { g/day }\end{array}$ & $\begin{array}{c}\text { Body weight } \\
\text { g }\end{array}$ \\
\hline 4 weeks old & $21.4 \pm 1.3$ & $4.47 \pm 0.3$ & $309.1 \pm 10.8$ \\
8 weeks old & $42.9 \pm 0.7$ & $8.71 \pm 0.4$ & $747.7 \pm 13.7$ \\
\hline
\end{tabular}

$\mathrm{n}=28$ for 4 weeks old birds; $\mathrm{n}=24$ for 8 weeks old birds 
The classical methods of balance measurements in birds are based on the cages with wire-netting floors and the excreta collection is carried out by using collection trays under them (Gažo et al., 1959; Sibbald and Wolynetz, 1986; Antalíková et al., 2001). The serious disadvantages of the tray technique are loss of excreta at the wire-netting floor, walls of the cage and legs of the birds. Eventually some part of the excrements can fall along the collection tray. The samples of excrements from a tray are usually contaminated with feathers, scales of the birds, spilled feed, water and various types of dust. These factors together can considerably influence the structure, composition and quantity of the samples for balance estimation.

The advantage of our approach and other known harness, bag or cup collection methods (Blakely, 1963; Sibbald, 1983, 1986; Almeida and Baptista, 1984; Adeola et al., 1997) is that excrements are free of any contamination and there are actually no excreta losses when the devices are properly fixed. On the other hand, birds equipped with devices for excreta collections face greater stress resulting in some reduction of feed intake. It has been shown that excretion of energy but not of nitrogen is impaired in birds fitted with harnesses and bags. The explanation of this finding is based on time spent on pecking at the devices and on the effects of such behaviour on peristalsis (Sibbald and Wolynetz, 1987).

In conclusion, the bag method described in this paper provides a simple and inexpensive tool for the quantitative collection of excrements in chicken. The main advantage of this technique is that excreta samples collected directly into PE bags are entirely without any losses and are not contaminated.

\section{AKNOWLEDGEMENTS}

We are grateful to Mrs. M. Stavrovská and Miss A. Rusková for the excellent technical assistance.

\section{REFERENCES}

Adeola O., Ragland D., King, D., 1997. Feeding and excreta collection technique in metabolizable energy assays for ducks. Poultry Sci. 76, 728-732

Almeida J.A., Baptista E.S., 1984. A new approach to the quantitative collection of excreta from birds in a true metabolizable energy bioassay. Poultry Sci. 63, 2501-2503

Antalíková J., Baranovská M., Mravcová I., Sabo V., Škrobánek P., 2001. Different influence of hypodynamy on calcium and phosphorus levels in bones of male and female japanese quails. Physiol. Res. 50, 197-204

Blakely R.M., 1963. Note on an apparatus for the collection of turkey faeces. Can. J. Anim. Sci. 43, 386-388

Gažo M., Landau L., Marcinka K., 1959. Calcium and phosphorus metabolism in laying hens on hypocalcemic diet (in Slovak). Pol'nohospodárstvo 6 (4), 583-598 
Jordan F.T.W., Pattison M. (Editors), 1996. Poultry Diseases. Appendix 1. W.B. Saunders Company Ltd., London, pp. 506

King D., Ragland D., Adeola O., 1997. Apparent and true metabolizable energy values of feedstuffs for ducks. Poultry Sci. 76, 1418-1423

Sibbald I.R., 1983. The T.M.E. system of feed evaluation. Tech. Bull., Res. Branch Agr. Ottawa, Ontario (Canada), Contrib. 1983-20E, p. 89

Sibbald I.R., 1986. The T.M.E. system of feed evaluation: methodology, feed composition data and bibliography. Anim. Res. Centre, Ottawa, Ontario (Canada), Contrib. 85-19

Sibbald I.R., Wolynetz M.S., 1986. Comparison of three methods of excreta collection used in estimation of energy and nitrogen excretion. Poultry Sci. 65, 78-84

Sibbald I.R., Wolynetz M.S., 1987. A comparison of the amounts of energy and nitrogen voided as excreta by cockerels housed over trays or fitted with harnesses and plastic collection bags. Poultry Sci. 66, 1987-1994

\section{STRESZCZENIE}

\section{Urządzenie do ilościowego zbierania wydalin u kurcząt w badaniach bilansowych}

Opisano prostą metodę ilościowego zbierania wydalin u kurcząt do woreczków plastikowych. Pióra w okolicy odbytu są usuwane i worek polietylenowy jest przymocowywany ściśle do ciała kurczęcia dokoła odbytu przy zastosowaniu obustronnej klejącej taśmy. W doświadczeniach bilansowych ptaki z dopasowanymi workami były utrzymywane w indywidualnych plastikowych klatkach przez 6 dni. Worki zmieniano każdego dnia w okresie bilansowym. Stwierdzono, że opisane urządzenie jest skuteczne i tanie i przydatne do ilościowej kolekcji wydalin u kurcząt; zapobiega stratom składników i zanieczyszczeniom paszą w czasie badań bilansowych. 